\title{
Blue Fescue Overseeding Improves Performance of Fairway Height Buffalograsses
}

\author{
Bekele G. Abeyo, Robert C. Shearman', Roch E. Gaussoin, \\ Leonard A. Wit, and Desalegn D. Serba \\ University of Nebraska-Lincoln, Department of Agronomy and Horticulture, \\ 377 Plant Science Lincoln, NE 68583-0724
}

\author{
Ugur Bilgili \\ Uludag University, Gorukle Campus, Department of Field Crops, 16059 \\ Bursa, Turkey
}

Additional index words. Turfgrass, Buchloe dactyloides, Festuca ovina

\begin{abstract}
Buffalograss [Buchloe dactyloides (Nutt.) Engelm.] use as a fairway turfgrass is limited in northern portions of its adaptation zone by its extended winter dormancy and tan coloration in early spring and late fall. Cool-season grasses mixed with buffalograss could enhance turfgrass appearance and performance in fall and early spring. Research was conducted near Mead, NE, with eight buffalograss genotypes maintained under fairway conditions to determine the effect of blue fescue (Festuca ovina L. var. glauca Lam.) overseeding rate on turfgrass performance. Interactions were nonsignificant in most cases so main effects are emphasized. Differences were observed between seeding rates and genotypes for most traits studied. Overseeding blue fescue enhanced spring green-up, fall color retention, stand density, and turfgrass quality. These effects were most pronounced in late fall and early spring, when buffalograss plants were entering or exiting winter dormancy. The $5 \mathrm{~g} \cdot \mathrm{m}^{-2}$ blue fescue overseeding rate improved all performance traits studied when compared with the nonoverseeded buffalograss control and was not different from the $10 \mathrm{~g} \cdot \mathrm{m}^{-2}$ seeding rate treatment. Thus, the $5 \mathrm{~g} \cdot \mathrm{m}^{-2}$ blue fescue overseeding rate appeared to be near optimum for overall turfgrass performance, offering reduced seed cost and decreased potential for species interference. The 'Legacy' buffalograss and 'SR-3200' blue fescue mixture had the best performance of the genotypes studied as a result of their visual compatibility in terms of color similarity.
\end{abstract}

Buffalograss is a warm-season perennial grass species that is native to the Great Plains of North America (Gould, 1979; Shearman et al., 2004; Wenger, 1943). It has excellent high-temperature tolerance (Shearman et al., 2004), drought resistance (Beard and Kim, 1989), and low input requirements. Buffalograss is used for lawns, sport turfs, golf course roughs and fairways, and for soil conservation and erosion control (Pozarnsky, 1983; Shearman et al., 2004). Buffalograss has a strong potential for use on fairways in regions where water is limiting (Shearman et al., 2004). Buffalograss performance decreases during winter dormancy as plants lose green color in fall through spring. The extended dormancy period may limit the acceptance of buffalograss turf, especially in northern climates and intensively used turf sites, like golf course fairways and sports fields (Shearman et al., 2004).

Overseeding cool-season grasses into warm-season grasses to temporarily extend turfgrass performance in the fall and winter is a common practice in the southern United States (Foy, 1998; Longer, 1998). However,

Received for publication 26 Feb. 2009. Accepted for publication 27 Apr. 2009.

${ }^{1}$ To whom reprint requests should be addressed; e-mail rshearman@unl.edu. efforts to establish long-term mixtures of warm- and cool-season turfgrasses have generally not been successful (Beard, 1973; Johnson, 2003). Researchers in Nebraska and Utah reported improved spring and fall green color retention in buffalograss turfs overseeded with fine fescue (Festuca species) on a long-term basis (Johnson, 2003; Severmutlu et al., 2005). Blue fescues are well adapted to dry situations and are good choices for low-maintenance turfgrass sites (Roberts, 1990). In Nebraska, overseeding buffalograss turfs maintained at lawn heights of cut with blue fescue resulted in improved turfgrass quality and green cover (Severmutlu et al., 2005). With these aspects in mind, this study was initiated to determine the effects of blue fescue overseeding on turfgrass fall and spring color retention and turfgrass performance of buffalograss genotypes maintained under golf course fairway conditions.

\section{Materials and Methods}

Eight buffalograss genotypes (i.e., 'Legacy', '378', 'Cody', NTG7, 86-120, 'Texoka', 'Prestige', and 'FW-3') were established on a Tomek silty-clay loam (fine, smectitic, mesic Pachic Argiudolls) in 2000 at the John Seaton Anderson Turfgrass Research Facility located near Mead, NE. Genotypes were maintained under fairway conditions and were mowed at $16 \mathrm{~mm}$ with clippings removed. Irrigation was supplied at $25 \mathrm{~mm}$ per month; when precipitation was $25 \mathrm{~mm}$ or greater per month. no irrigation was applied. Turfs received $10 \mathrm{~g}$ $\mathrm{N} / \mathrm{m}^{2} /$ season applied as $5 \mathrm{~g} \mathrm{~N} / \mathrm{m}^{2}$ in June and July.

The experimental design was a randomized complete block design with a split-plot treatment arrangement. Main plots were blue fescue overseeding rates (i.e., control, 5 and $10 \mathrm{~g} \cdot \mathrm{m}^{-2}$ ), and subplots were the eight buffalograss genotypes. Treatments were replicated three times. Two experiments were conducted. The first was initiated in Sept. 2004 and the second in Sept. 2005.

In early Sept. 2004 and 2005 for the first and second studies, respectively, a single core cultivation was applied to the treatment plots using a Cushman (GA30, Lincoln, NE; no longer manufactured). Core cultivation was performed with 16-mm o.d. hollow tines to a 76$\mathrm{mm}$ depth using 50-mm spacing. 'SR 3200' blue fescue was overseeded into buffalograss genotypes at 5 and $10 \mathrm{~g} \cdot \mathrm{m}^{-2}$ using a drop spreader immediately after the core cultivation, and a nonoverseeded control was included; and these plots were core cultivated as well.

A starter fertilizer $(16 \mathrm{~N}-11 \mathrm{P}-10 \mathrm{~K})$ was applied at $5 \mathrm{~g} \mathrm{~N} / \mathrm{m}^{2}$ after overseeding. The turf was irrigated three times daily at $6 \mathrm{~mm}$ for 3 weeks and then at $12 \mathrm{~mm}$ weekly for the remainder of the growing season. After the establishment period in the fall, the turfs were mowed at $16 \mathrm{~mm}$, three times per week with the clippings returned, irrigated at $25 \mathrm{~mm}$ per month, and fertilized with $5 \mathrm{~g} \mathrm{~N} / \mathrm{m}^{2}(46 \mathrm{~N}$ $0 \mathrm{P}-0 \mathrm{~K}$ ) in June and July. A second study was initiated in early Sept. 2005. All procedures, treatments, and maintenance were the same as those described for the 2004 study.

Data were collected on: 1) spring greenup using a visual rating scale of 1 to 9 with $1=$ dormant turf and $9=$ dark green, actively growing turf; 2) turf color using a visual rating scale of 1 to 9 with $1=$ light brown, $6=$ light green, and $9=$ dark green; 3 ) density using a visual estimate of species cover based on a 1 to 9 scale with $1=0 \%$ to $15 \%$, and $9=$ $85 \%$ to $100 \%$; and 4 ) turfgrass quality was rated monthly using a 1 to 9 visual rating scale with $1=$ poorest, $5=$ acceptable, and $9=$ best. Three 100-mm diameter plugs were taken randomly from each treatment plot in July 2006 for both studies. The shoot density of each species was counted, averaged for the three samples, and reported as number $\times 10^{4} / \mathrm{m}^{2}$.

Data were analyzed using PROC GLM (SAS Institute, 1999) and means were separated by Fisher's least significant differences $(P<0.05)$. A Hartley's F max test (Hartley, $1950)$ was used to test homogeneity of variances between studies.

\section{Results and Discussion}

The Hartley F max test (Hartley, 1950) resulted in homogeneity of variance between the two studies for spring green-up, color, density, quality, and species shoot density. 
Therefore, these data were combined for 2005 and 2006.

Seeding rate $\times$ genotype interaction was significant only for buffalograss shoot density indicating that buffalograss genotypes responded differently to blue fescue overseeding rates (Tables 1 and 2). Differences occurred among blue fescue seeding rates for all traits except the quality rating taken in June. These differences were between the nonoverseeded control and the seeding rates (Tables 3 and 4), indicating that overseeding buffalograss with blue fescue enhanced the overall turf performance under fairway conditions. Spring green-up increased from 3.4 for the nonoverseeded control to 4.5 and 5.5, respectively, for the 5 and $10 \mathrm{~g} \cdot \mathrm{m}^{-2}$ seeding rates (Table 3 ). This response was attributable primarily to the actively growing blue fescue plants compared with the dormant buffalograss in the nonoverseeded control treatment.

Blue fescue overseeding rates also influenced density and composition of the species. Density increased from 6.0 for the control to 6.1 and 6.6 , respectively, for 5 and $10 \mathrm{~g} \cdot \mathrm{m}^{-2}$ seeding rates (Table 3 ). An average of $173 \%$ and $183 \%$ greater shoots per unit area were counted for the 5 and $10 \mathrm{~g} \cdot \mathrm{m}^{-2}$ seeding rates, respectively, compared with the buffalograss monostand. Buffalograss shoot density was twice as much in the monostand as in the mixture. Watschke and Schmidt (1992) reported that most turfgrass communities are composed of polystands that are competing for light, water, nutrients, $\mathrm{CO}_{2}, \mathrm{O}_{2}$, and space; thus, each plant has a minimum survival requirement for these resources. Higher blue fescue shoots were counted per unit area as opposed to buffalograss shoots (Table 3). Although this was the case, the visual turf appearance was characteristic of a typical buffalograss turf. The mixture plots consisted of $71 \%$ blue fescue and $29 \%$ buffalograss shoots per unit area in summer, whereas Severmutlu et al. (2005) reported botanical composition of the mixtures reaching $75 \%$ to $80 \%$ fine fescue and $20 \%$ to $25 \%$ buffalograss in the fall. Their study was conducted at lawn heights of cut (i.e., $63 \mathrm{~mm}$ ), whereas this study was maintained at a $16-\mathrm{mm}$ mowing height. Watschke and Schmidt (1992) in their review article stated that differences in soil properties, growth habit, stress tolerance, management practices, and plant competition alter species composition. The change in plant composition might be the result of the difference in morphological characteristics of the species competing for the resources in response to the differences in mowing height as well as the prevalent environmental conditions.

More dense turfgrass stands generally have higher turfgrass quality ratings. As a result, an average of 2.1 and 2.5 (on 1 to 9 scale) improvement in turfgrass quality ratings was obtained over the control for the 5 and $10 \mathrm{~g} \cdot \mathrm{m}^{-2}$ blue fescue seeding rates, respectively, over the season (Table 4). This response was primarily the result of increased spring green-up, stand density, groundcover, color, and fall green color retention ratings. The most pronounced improvements were observed during the late fall and early spring evaluations when buffalograss was dormant. In Utah, Johnson (2003) reported a buffalograss-blue fescue mixture had the best overall quality and uniformity compared with the other fine fescue-buffalograss mixtures. In Nebraska, researchers also found buffalograssblue fescue mixtures maintained acceptable quality ratings during summer stress and good

color retention in fall and spring (Severmutlu et al., 2005; Shearman et al., 2006).

Environmental conditions may also influence seeding rate recommendations (Watschke and Schmidt, 1992). Under the conditions of this study, the $5 \mathrm{~g} \cdot \mathrm{m}^{-2}$ blue fescue overseeding rate improved all performance traits studied when compared with the nonoverseeded control (Tables 3 and 4) and was not

Table 1. Analysis of variance for spring green-up, color, density, and species shoot count of eight buffalograss genotypes overseeded with blue fescue at two seeding rates and grown at John Seaton Anderson Turfgrass Research Facility located near Mead, NE. ${ }^{z}$

\begin{tabular}{|c|c|c|c|c|c|c|c|}
\hline \multirow[b]{4}{*}{ Source } & \multirow[b]{4}{*}{$\mathrm{df}$} & \multicolumn{6}{|c|}{ Mean Squares } \\
\hline & & \multirow[b]{2}{*}{$\begin{array}{l}\text { Spring } \\
\text { green-up }^{y}\end{array}$} & \multirow[b]{2}{*}{ Color $^{x}$} & \multirow[b]{2}{*}{ Density $^{w}$} & \multicolumn{2}{|c|}{ Species shoot count $^{v}$} & \multirow[b]{3}{*}{$\mathrm{BF} / \mathrm{BFG}$ ratio } \\
\hline & & & & & $\begin{array}{c}\text { Buffalograss } \\
\text { (BFG) }\end{array}$ & $\begin{array}{c}\text { Blue fescue } \\
\text { (BF) }\end{array}$ & \\
\hline & & Mar. & June & June & July & July & \\
\hline$\overline{\text { Repetitions }}$ & 2 & 0.8 & 0.5 & 2.9 & 397.1 & $2,257.4$ & 0.3 \\
\hline \multicolumn{8}{|l|}{ Seeding } \\
\hline rate (SR) & 2 & $53.1^{* *}$ & $6.9 *$ & $4.9 *$ & $79,325.3 * *$ & $541,199.3 * *$ & $127.0 * *$ \\
\hline Error a & 4 & 0.3 & 0.4 & 0.4 & 393.6 & $2,695.3$ & 0.6 \\
\hline Genotypes (G) & 7 & $6.4^{* *}$ & $2.6^{*}$ & $3.6^{*}$ & $1,118.1^{*}$ & $1,510.1$ & $4.6^{*}$ \\
\hline $\mathrm{SR} \times \mathrm{G}$ & 14 & 0.4 & 0.3 & 0.3 & $1,018.1 *$ & $2,405.2$ & 1.2 \\
\hline Error b & 114 & 0.7 & 1.0 & 1.4 & 523.8 & $1,911.1$ & 1.7 \\
\hline $\mathrm{cv}(\%)$ & & 18.4 & 16.3 & 18.9 & 23.3 & 35.7 & 68.2 \\
\hline
\end{tabular}

${ }^{\mathrm{z}}$ Data are combined from 2005 and 2006.

${ }^{y}$ Spring green-up was visually rated on a 1 to 9 scale where $1=$ light brown dormant turf and $9=$ dark green actively growing turf.

${ }^{\mathrm{x}}$ Color was visually rated on a 1 to 9 scale where $1=$ light brown, $6=$ light green, and $9=$ dark green turf color.

${ }^{w}$ Density was visually rated on a 1 to 9 scale where $1=0 \%$ to $10 \%$ and $9=90 \%$ to $100 \%$.

${ }^{v}$ Species shoot counts of each species were made from three 100-mm diameter plugs taken from each treatment plot and reported as number $\times 10^{4} / \mathrm{m}^{2}$.

$*, * *=$ Significant at $P=0.05$ and 0.01 , respectively.

Table 2. Analysis of variance for monthly turfgrass quality ratings of eight buffalograss genotypes overseeded with blue fescue at two seeding rates and grown at John Seaton Anderson Turfgrass Research Facility located near Mead, NE. ${ }^{\mathrm{z}}$

\begin{tabular}{lccccccc}
\hline & & \multicolumn{5}{c}{ Mean Squares } \\
\cline { 3 - 7 } & & \multicolumn{7}{c}{ Turfgrass quality } \\
\cline { 3 - 7 } Source & df & June & July & Aug. & Sept. & Oct. & Mean \\
\hline Repetitions & 2 & 6 & 13.4 & 11.3 & 13.6 & 21.3 & 8.9 \\
Seeding rate (SR) & 2 & 1.6 & $15.4^{*}$ & $24.1^{*}$ & $59.4^{*}$ & $95.1^{*}$ & $22.5^{* *}$ \\
Error a & 4 & 0.6 & 2.4 & 1.4 & 4.3 & 6.4 & 1.2 \\
Genotypes (G) & 7 & $11.0^{* *}$ & $3.8^{* *}$ & $2.0^{* *}$ & $3.6^{* *}$ & 4.3 & $2.1^{* *}$ \\
SR $\times$ G & 14 & 0.4 & 0.4 & 0.9 & 0.7 & 1.4 & 0.3 \\
Error b & 114 & 0.6 & 0.6 & 0.7 & 1.0 & 2.4 & 0.4 \\
cv (\%) & & 14.6 & 13.9 & 14.9 & 21.8 & 44.5 & 12.9 \\
\hline
\end{tabular}

${ }^{\mathrm{z}}$ Data are combined from 2005 and 2006.

y Turfgrass quality was visually rated on a 1 to 9 scale where $1=$ poorest, $5=$ acceptable, and $9=$ best. $*, * *=$ Significant at $P=0.05$ and 0.01 , respectively.

Table 3. Mean spring green-up, turfgrass color, density, quality, and species shoot counts for buffalograss mixtures with blue fescue and compared with nonoverseeded buffalograss control. ${ }^{z}$

\begin{tabular}{|c|c|c|c|c|c|c|}
\hline \multirow{4}{*}{$\begin{array}{l}\text { Seeding } \\
\text { rate }\left(\mathrm{g} \cdot \mathrm{m}^{-2}\right)\end{array}$} & \multirow{3}{*}{$\begin{array}{c}\text { Spring } \\
\text { green-up }\end{array}$} & \multirow[b]{3}{*}{ Color $^{x}$} & \multirow[b]{3}{*}{ Density $^{\mathrm{w}}$} & \multirow{2}{*}{\multicolumn{2}{|c|}{$\frac{\text { Species shoot count }^{\mathrm{v}}}{\text { No. } \times 10^{4} / \mathrm{m}^{2}}$}} & \multirow{4}{*}{$\begin{array}{c}\text { Blue fescue } \\
\text { composition }(\% \\
\text { of the mixture }\end{array}$} \\
\hline & & & & & & \\
\hline & & & & Buffalograss & Blue fescue & \\
\hline & Mar. & June & June & July & July & \\
\hline 0 & 3.4 & 5.5 & 6.0 & 1.85 & 0 & 0 \\
\hline 5 & 4.5 & 6.1 & 6.1 & 0.94 & 2.27 & 71 \\
\hline 10 & 5.5 & 6.3 & 6.6 & 0.97 & 2.41 & 72 \\
\hline $\begin{array}{l}\text { Least significant } \\
\text { difference }(0.05)\end{array}$ & 0.3 & 0.4 & 0.4 & 0.45 & 0.37 & \\
\hline
\end{tabular}

zTurfs were grown at Mead, NE. Data are from 2005 and 2006.

${ }^{y}$ Spring green-up was visually rated on a 1 to 9 scale where $1=$ light brown dormant turf and $9=$ dark green actively growing turf.

${ }^{\mathrm{x}}$ Color was visually rated on a 1 to 9 scale where $1=$ light brown and $9=$ dark green turfgrass color.

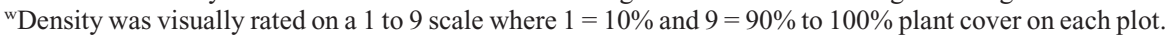
${ }^{\mathrm{v}} \mathrm{Species}$ shoot count $=$ shoots of each species were counted from 100-mm diameter plugs of each plot and reported as number of shoots $/ \mathrm{m}^{2}$. 
Table 4. Monthly turfgrass quality for buffalograss mixtures with blue fescue and compared with a nonoverseeded buffalograss control. ${ }^{\mathrm{z}}$

\begin{tabular}{llllcc}
\hline \multirow{2}{*}{$\begin{array}{l}\text { Seeding } \\
\text { rate }\left(\mathrm{g} \cdot \mathrm{m}^{-2}\right)\end{array}$} & \multicolumn{5}{c}{ Turfgrass quality } \\
\cline { 2 - 6 } & June & July & Aug. & Sept. & Oct. \\
\hline 0 & 5.5 & 5 & 4.7 & 3.4 & 1.9 \\
5 & 5.4 & 6.1 & 5.8 & 4.9 & 3.9 \\
10 & 5.7 & 6 & 6 & 5.6 & 4.6 \\
Least significant & 0.4 & 0.9 & 0.7 & 1.2 & 1.4 \\
$\quad$ difference & & & & & \\
$\quad(0.05)$ & & & & &
\end{tabular}

${ }^{\mathrm{z}}$ Turfs were grown at Mead, NE. Data are from 2005 and 2006.

${ }^{\mathrm{y}}$ Turfgrass quality was visually rated on a 1 to 9 scale where $1=$ poorest $5=$ acceptable, and $9=$ best turf.

significantly different from the $10 \mathrm{~g} \cdot \mathrm{m}^{-2}$ seeding rate treatment for the parameters studied with the exception of the spring green-up rating. Thus, the $5 \mathrm{~g} \cdot \mathrm{m}^{-2}$ blue fescue overseeding rate appeared to provide effective overall turfgrass performance with less potential species competition and reduced seed cost inputs.

Differences were observed among buffalograss genotypes tested for spring green-up, turfgrass density and quality, and buffalograss shoot count (Tables 5 and 6). 'Legacy', NTG7, and 'Texoka' greened-up early, whereas 'Prestige', '378', and 'Cody' greened-up late. Legacy maintained good turfgrass color ratings across the seeding rates, whereas ' $\mathrm{FW}-3$ ' and ' 378 ' had the poorest ratings. 'Legacy' was the only cultivar with superior performance for all the traits (Tables 5 and 6). Based on superior performance and color compatibility with blue fescue, 'Legacy' performed best in these growing conditions. These results indicate that the success of overseeding buffalograss genotypes with fine fescue species may be dependent on selecting compatible turfgrass color types as well as compatibility relating to species competition. Hence, careful selection of the right buffalograss cultivar with improved adaptation and compatibility with blue fescue cultivars exhibiting similar traits is a necessity for enhanced turfgrass quality under fairway management conditions.

\section{Conclusion}

Overseeding buffalograss genotypes with blue fescue maintained under fairway conditions provided an attractive groundcover during the extended winter dormancy of buffalograss. The $5 \mathrm{~g} \cdot \mathrm{m}^{-2}$ blue fescue overseeding rate was as effective as the $10 \mathrm{~g} \cdot \mathrm{m}^{-2}$ so, based on these findings, would be the recommended overseeding rate on buffalograss maintained at fairway heights of cut. These blue fescue overseedings enhanced spring green-up, turf color, and turfgrass quality of buffalograss maintained under fairway conditions. Although quality differences were higher between the control and overseeded treatments, during early spring and late fall, improvements in quality were observed throughout the growing season. The mixture of blue fescue-buffalograss created

Table 5. Mean spring green-up, color, and species shoot counts of eight buffalograss genotypes overseeded with blue fescue at two seeding rates and grown at John Seaton Anderson Turfgrass Research Facility located near Mead, NE. ${ }^{\mathrm{z}}$

\begin{tabular}{|c|c|c|c|c|c|}
\hline \multirow[b]{4}{*}{ Genotype } & \multirow[b]{3}{*}{ Spring green-up ${ }^{y}$} & \multirow[b]{3}{*}{ Color $^{\mathrm{x}}$} & \multirow[b]{3}{*}{ Density $^{\mathrm{w}}$} & \multirow{2}{*}{\multicolumn{2}{|c|}{$\frac{\text { Species shoot count }^{\mathrm{v}}}{\text { No. } \times 10^{4} / \mathrm{m}^{2}}$}} \\
\hline & & & & & \\
\hline & & & & Buffalograss & Blue fescue \\
\hline & Mar. & June & June & July & July \\
\hline Legacy & 4.9 & 6.8 & 6.8 & 1.25 & 1.58 \\
\hline 378 & 4.4 & 5.5 & 6.2 & 1.28 & 1.54 \\
\hline Cody & 4.4 & 5.9 & 5.8 & 1.21 & 1.6 \\
\hline NTG7 & 4.9 & 5.8 & 6 & 1.3 & 1.49 \\
\hline $86-120$ & 4.4 & 6 & 6.9 & 1.36 & 1.48 \\
\hline Texoka & 4.8 & 6 & 5.6 & 1.26 & 1.45 \\
\hline Prestige & 3.1 & 6.1 & 6.2 & 1.03 & 1.82 \\
\hline FW-3 & 4.6 & 5.7 & 6.3 & 1.33 & 1.51 \\
\hline \multicolumn{6}{|l|}{ Least significant } \\
\hline difference $(0.05)$ & 0.5 & 0.6 & 0.8 & 0.59 & 0.37 \\
\hline
\end{tabular}

${ }^{\mathrm{z}}$ Data are combined for 2005 and 2006.

${ }^{y}$ Spring green-up was visually rated on a 1 to 9 scale where $1=$ light brown dormant turf and $9=$ dark green actively growing turf.

${ }^{\mathrm{x}}$ Color was visually rated on a 1 to 9 scale where $1=$ light brown and $9=$ dark green turfgrass color.

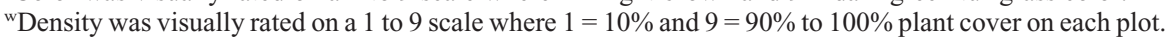
${ }^{\mathrm{v}}$ Species shoot count $=$ shoots of each species were counted from 100-mm diameter plugs of each plot and reported as number of shoots $/ \mathrm{m}^{2}$.

Table 6. Monthly turfgrass quality of eight buffalograss genotypes grown at John Seaton Anderson Turfgrass Research Facility located near Mead, NE. ${ }^{z}$

\begin{tabular}{lcccccc}
\hline & \multicolumn{5}{c}{ Turfgrass quality $^{\mathrm{y}}$} \\
\cline { 2 - 7 } Genotype & June & July & Aug. & Sept. & Oct. & Mean \\
\hline Legacy & 6.8 & 6.6 & 6.0 & 5.3 & 4.1 & 5.9 \\
378 & 4.9 & 5.8 & 5.7 & 4.4 & 3.4 & 5.1 \\
Cody & 5.0 & 5.4 & 5.8 & 5.1 & 3.9 & 5.2 \\
NTG7 & 5.1 & 5.1 & 5.2 & 4.2 & 3.2 & 4.8 \\
$86-120$ & 6.7 & 5.9 & 5.2 & 4.1 & 2.7 & 5.3 \\
Texoka & 5.2 & 5.3 & 5.5 & 4.8 & 3.9 & 5.1 \\
Prestige & 5.1 & 5.9 & 5.5 & 4.8 & 3.2 & 5.1 \\
FW-3 & 5.3 & 5.5 & 5.1 & 4.2 & 3.1 & 4.9 \\
Mean & 5.5 & 5.7 & 5.5 & 4.6 & 3.5 & 5.2 \\
Least significant & 0.5 & 0.5 & 0.5 & 0.7 & 1.0 & 0.4 \\
$\quad$ difference (0.05) & & & & & &
\end{tabular}

${ }^{\mathrm{z}}$ Data are combined from 2005 and 2006.

${ }^{\mathrm{y}}$ Turfgrass quality was visually rated on a $1=9$ scale where $1=$ poorest, $5=$ acceptable, and 9 is the best.

a more attractive green color than the buffalograss monostand. The 'Legacy'-blue fescue mixture produced the best overall turf quality and darkest green color. Thus, selecting the right combination of blue fescue and buffalograss genotypes is important in determining the overall performance of the cooland warm-season turfgrass mixture under fairway conditions.

\section{Literature Cited}

Beard, J.B. 1973. Turfgrass: Science and culture. Prentice-Hall, Inc., Englewood Cliffs, NJ.

Beard, J.B. and K.S. Kim. 1989. Low-water-use turfgrasses. USGA Green Section Record. 27:12-13.

Foy, J.H. 1998. The pros and cons of fairway overseeding. Green Section Record. 36:50-55.

Gould, F.W. 1979. A key to genera of Mexican grasses. Texas Agr. Exp. Sta. Pub. MP-1422. Texas A\&M Univ., College Station, TX.

Hartley, H.O. 1950. The maximum F-ratio as a shortcut test for heterogeneity of variance. Biometrika 37:308-312.

Johnson, P.G. 2003. Mixtures of buffalograss and fine fescue or stream bank wheatgrass as a lowmaintenance turf. HortScience 38:1214-1217.

Longer, D.E. 1998. Overseeding warm season lawns with cool season turfgrass species, $\mathrm{p}$.
72-75. In: Clark, J.R. and M.D. Richardson (eds.). Horticultural studies 1998 (Research series 466). Ark. Agr. Exp. Stn. Univ. of Ark. Div. of Agr., Fayetteville, AR.

Pozarnsky, T. 1983. Buffalograss: Home on the range, but also a turfgrass. Rangelands 5:214216.

Roberts, E.C. 1990. Fine fescue: A kinder, gentler lawn grass. Seed World 28:16-19.

SAS Institute. 1999. SAS/STAT user's guide. Release 8.0 SAS Inst., Cary, NC.

Severmutlu, S., T.P. Riordan, R.S. Shearman, R.E. Gaussoin, and L.E. Moser. 2005. Overseeding buffalograss turf with fine-leaved fescues. Crop Sci. 45:704-711.

Shearman, R.C., T.P. Riordan, and P.G. Johnson. 2004. Buffalograss, p. 1003-1026. Analysis. Monograph Series No. 43. American Society of Agronomy, Madison, WI.

Shearman, R.C., S. Severmutlu, T.P. Riordan, and U. Bilgili. 2006. Overseeding fine fescue in buffalograss turfs. USGA Green Section Record. 44:20-25.

Watschke, T.E. and R.E. Schmidt. 1992. Ecological aspects of turf communities, p. 129-174. In: Waddington, D.V., R.N. Carrow, and R.C. Shearman (eds.). Turfgrass science. Agron. Monogr. No. 32. ASA, CSSA, and SSSA, Madison, WI.

Wenger, L.E. 1943. Buffalo grass. Bull. 321. Kan. Agric. Exp. Stn., Manhattans, KS. 